\title{
Academic Entrepreneurs and Entrepreneurial Academics: Are They the Same
}

\author{
Kizito Emmanuel Nyeko and Ngui Kwang Sing
}

\begin{abstract}
Some scholars have attempted to define academic entrepreneurship by classifying academics based on the types of entrepreneurial activities that they are engaged in thus academic entrepreneurship is described as the third mandate of academia. The purpose of this paper is to review and synthesise the literature on the classification of academic entrepreneurs. Three distinct identities of academic entrepreneurs are described, namely, the academic entrepreneur, the entrepreneurial academic, and the academic-entrepreneur. The nature and essence of entrepreneurship of each identity is discussed, based on the; types of activities, challenges academics face, and opportunities available. Propositions presented include; commercialisation is only one of many possible outcomes of academic entrepreneurship, different entrepreneurial activities may require different support to nurture entrepreneurial academics and researchers, and need to further explore how commercialisation can be an agenda for all entrepreneurial activities as it influences sustainability of entrepreneurial initiatives. The paper concludes by calling for further work on integrating academic and entrepreneurial identities.
\end{abstract}

Index Terms-Academic entrepreneurs, academic entrepreneurship, entrepreneurial university.

\section{INTRODUCTION}

Universities perform essential roles in creating and transmitting new knowledge within contemporary societies [1]-[3]. Academic entrepreneurship has started to be considered a third mission in which university institutions engage, in addition to the traditional mandates of teaching and research. To encourage entrepreneurship among academics and students, universities are now developing entrepreneurship polices and implementing these initiatives to embed entrepreneurial thinking and practices within teaching, research and administration [4].

This phenomenon has been described as the academic revolution [5], [6] and has resulted in the emergence of various types of universities, such as, research universities, technological universities, teaching universities, hybrid universities and of late, entrepreneurial universities.

However, findings from various studies show evidence that the performance of the 'third mission' differs widely among academics. This brings to the forefront the need to understand the different academic entrepreneurs who engage in entrepreneurial activities [7], [8].

It is crucial that universities, government, industry and

Manuscript received June 14, 2014; revised August 22, 2014.

The authors are with Swinburne University of Technology, Sarawak Campus, Sarawak, Malaysia (email: kenyeko@swinburne.edu.my, kngui@swinburne.edu.my ). public get to understand entrepreneurial productivity and performance from the academic entrepreneur's point of view in order to optimise performance outcomes of entrepreneurial ventures [9]-[11].

The main goal of this paper is to describe three classifications of academic entrepreneurs involved in academic entrepreneurship, namely, the academic entrepreneur; the entrepreneurial academic and the academic-entrepreneur.

The structure of the paper is as follows. In Section II, the concept of academic entrepreneurship is introduced, while in Section III, the different classifications of academics as entrepreneurs are presented. In Section IV, the challenges faced by academics and relevant stakeholders in transforming traditional universities into entrepreneurial universities are discussed, while opportunities for academic entrepreneurship are discussed in Section V. Lastly, a number of recommendations for facilitating academic entrepreneurship are presented in Section VI.

\section{ACADEMIC ENTREPRENEURSHIP}

In Malaysia, academic entrepreneurship is an emerging research area with research into technology commercialization receiving the most attention [12], [13].

In a university setting, academic entrepreneurship is the synthesis and integration of scientific, academic and commercial activities [14]-[17]. It is often characterised by formal arrangements to commercialise academic intellectual property through knowledge (e.g. consulting or contract research), transfer of technology (e.g. patent or licensing) and transfer of products or services (e.g. spin offs) [18].

Academic entrepreneurship occurs at the level of individuals or groups of individuals acting independently or as part of faculty or university systems, who create new organizations, or instigate innovation within or outside the university [19].

Given this background, [20] identified three dimensions of academic entrepreneurship, namely, organisational creation; organisational innovation; and organisational renewal in Table I below. The organisational creation dimension involves the deployment of mechanisms such as the setting-up of start-up companies, university spin-offs and joint ventures, in pursuit of academic entrepreneurship actions. The organisational innovation dimension involves the creation and commercialisation of new value, through mechanisms such as research groups and research centres. The organisational renewal dimension involves sustaining entrepreneurship through mechanisms of technology transfer schemes, patenting, design rights and licensing agreements. 
TABLE I: DIMENSIONS AND MECHANISMS OF ACADEMIC ENTREPRENEURSHIP

\begin{tabular}{|c|c|}
\hline Dimensions & Mechanisms \\
\hline $\begin{array}{l}\text { Organisational creation- } \\
\text { Venture creation by expanding } \\
\text { operations in existing or new } \\
\text { markets through university } \\
\text { start-ups, companies, spin-offs or } \\
\text { spin-outs and strategic alliances, } \\
\text { joint ventures or collaboration with } \\
\text { industry. }\end{array}$ & $\begin{array}{l}\text { Start-up companies; University } \\
\text { spin-offs; } \\
\text { Joint- venture }\end{array}$ \\
\hline $\begin{array}{l}\text { Organisational innovation- } \\
\text { The university's commitment to } \\
\text { pursue research and development in } \\
\text { creating and introducing scientific } \\
\text { breakthrough, new inventions and } \\
\text { products; introducing new ways of } \\
\text { doing things in terms of production } \\
\text { processes and organisational } \\
\text { systems within the university; and; } \\
\text { transferring and commercialising } \\
\text { new knowledge and technology for } \\
\text { economic and social development }\end{array}$ & $\begin{array}{l}\text { Research groups; } \\
\text { Research centers }\end{array}$ \\
\hline $\begin{array}{l}\text { Organisational renewal- } \\
\text { The transformation of the existing } \\
\text { academic organisations through the } \\
\text { renewal or reshaping of the ideas in } \\
\text { which they are built; by building or } \\
\text { acquiring new capabilities and then } \\
\text { creatively leveraging them to add } \\
\text { value for stakeholders; and through } \\
\text { revitalizing the organisation's } \\
\text { operations by changing the scope of } \\
\text { its business, its competitive } \\
\text { approach or both }\end{array}$ & $\begin{array}{l}\text { Technology transfer; Schemes; } \\
\text { Patenting; } \\
\text { Licensing; } \\
\text { Design rights }\end{array}$ \\
\hline
\end{tabular}

\section{ACADEMICS AS ENTREPRENEURS}

Literature on the nature of academic work describes an academic as someone who works within a university, juggling the roles of generating new knowledge (research) and transmitting knowledge (teaching) with administrative duties [21]. These roles have been described as the traditional mandates of academics as employees of universities.

Some scholars have attempted to define academic entrepreneurship by classifying academics based on the types of entrepreneurial activities that they are engaged in. Three general classifications of academics are the academic entrepreneur, the entrepreneurial academic and the academic-entrepreneur.

The academic entrepreneur is one who engages in the commercialisation of academic intellectual property [17]. This term has become more known because of a few productive individuals who took initiative in universities and created successful commercial endeavours [22].

The entrepreneurial academic is a managerial change agent in university, who builds research and teaching enterprises outside the conventional walls of the university, and in most cases relying almost entirely on external funding sources, gathering their own research teams, competing for or joining research grants, concluding contracts with industry and including graduates into research teams [23]. They engage in various forms of entrepreneurial behaviours in academia related to teaching, research, administration or consulting [24].

The academic-entrepreneur is one who engages in commercial activities outside academia with or without the involvement of the university [25], [26]. They have two career options, namely, to quit academia and start a business while employed in academia [27].

The classifications of academics based on the types of activities they are engaged in are summarized in Table II below adapted from [28].

TABLE II: CLASSIFICATION OF ACADEMICS BASED ON THE TYPES OF ENTREPRENEURIAL ACTIVITIES THAT THEY ARE ENGAGED IN

\begin{tabular}{|c|c|}
\hline Academic & Related entrepreneurial activities \\
\hline Academic entrepreneur & $\begin{array}{l}\text { Teaching related activities } \\
\text { 1. External teaching } \\
\text { 2. Initiating the development of } \\
\text { new degree programmes } \\
\text { 3. Conducting seminars and } \\
\text { training sessions for } \\
\text { academia and industry }\end{array}$ \\
\hline Entrepreneurial academic & $\begin{array}{l}\text { Teaching and Research related activities } \\
\text { 1. Working in the industry } \\
\text { (research based) } \\
\text { 2. Research based consultancy for } \\
\text { industry through the } \\
\text { university } \\
\text { 3. Research based consultancy } \\
\text { privately (but without } \\
\text { forming a company) } \\
\text { 4. Developing products or } \\
\text { services with potential for } \\
\text { commercialisation } \\
\text { 5. Acquiring research funding } \\
\text { (grants) from government, } \\
\text { non-governmental or } \\
\text { international bodies (those } \\
\text { without collaboration with } \\
\text { industry) } \\
\text { 6. Collaboration with industry } \\
\text { through joint research } \\
\text { projects } \\
\text { Research related assistance to } \\
\text { small business owners }\end{array}$ \\
\hline Academic-entrepreneur & 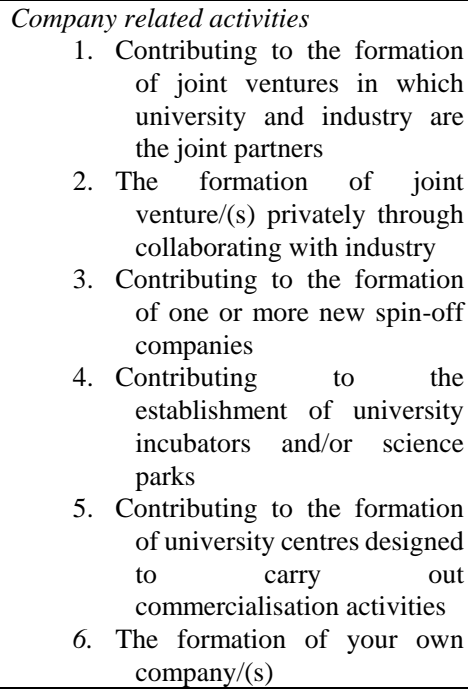 \\
\hline
\end{tabular}

\section{Challenges Facing ACAdemics in ACADEmic ENTREPRENEURSHIP}

Although education and research have traditionally been the university's main missions, this has gradually changed with the emergence of new perspectives on the role of the university in the system of intellectual property generation, production, sharing and distribution. [29] argues this 3rd university mission involving academic entrepreneurship, opens the possibility for many higher education institutions 
to get a broader source of funding from non-governmental or public organisations.

The adaption and adoption of "entrepreneurial flair" into the university appears to create discontent among academics to whom as the concept of entrepreneurship implies the creation of a new venture and income generation [4].

Literature reviewed highlight various challenges facing academicians and stake holders involved in face when transforming traditional universities into entrepreneurial universities as a result of universities engaging in activities beyond what they traditionally do, and are familiar with [30], [31]. The following sections describe the challenges that confront the academic entrepreneur, the entrepreneurial academic and the academic-entrepreneur.

\section{A. Academic Entrepreneur}

\section{1) Role overload for academicians}

The role of an academic and researcher and for some, administrative duties is already preexisting work burden. With the new role of becoming academic entrepreneurs, the major issue arising is the changing nature of academic work specifically properly prioritizing and juggling the roles of generating new knowledge (research), transmitting knowledge (teaching) and income generation (entrepreneur) [13], [15], [18].

\section{2) Lack of entrepreneur-owned resources}

Academics have to deal with enormous lack of resources impact the ability to be entrepreneurial will performing their roles as an academic. These include; limited financial resources, increasing capital costs, lack of infrastructure, delay in fund management and difficulty in finding private sector collaboration [30], [31].

\section{B. Entrepreneurial Academic}

\section{1) Unattractive incentive packages}

To be entrepreneurial in their various roles of research, teaching and administration requires extra effort, dedication and commitment from academics due to various uncertainties encountered [32]-[33]. To induce individual academics to embrace the new role of entrepreneurial academic, universities must distribute attractive incentives to them.

However, research findings reveal the high prevalence of unattractive incentive packages, for example, little or no royalty holding, little or no equity holding, little or no transfer fees and disagreements over intellectual property ownership causing dissatisfaction among entrepreneurial academics negatively impacting their involvement in such activities [34], [35].

\section{2) Absence of entrepreneurial role model and expert}

Literature describes an academic as someone who works in a university, juggling the roles of research, teaching and administrative duties [21]. Studies on entrepreneurial universities in Taiwan and Korea attribute the main reason for the lack of success in innovation and commercialization initiatives to the absence of entrepreneurial role model and expert [19].

With universities embracing entrepreneurial thinking and practices in their operations, the challenge is the absence of university entrepreneurial role model and expert to guide entrepreneurial academics with little or no management and business experience to identify (business/market) entrepreneurial opportunities and act upon them given the diverse experts and personal entrepreneurial inclinations [47], [84].

\section{Academic-Entrepreneur}

\section{1) Academics perception of the original purpose of university existence}

Academic-entrepreneurs engage in commercial activities outside academia with or without the involvement of the university [32], [35]. There activities cause a loss of time allocated for the traditional academic roles of basic research, teaching and administrative duties challenging academics perception of the original purpose of university existence.

Findings from previous studies on academics involved in academic entrepreneurship suggest many academics argue the role of the university is not to "do business" but to "support business", which reflects the fundamental understanding of the nature of universities [36].

Given the perceptions of fellow academics and uncertainty of outcomes, it is a challenge for academic-entrepreneurs to get peer and institutional support for their initiatives. Globally, only a few universities make lucrative income from academic-entrepreneurs led initiatives, for example, Stanford, MIT, and University of California [19], [37].

\section{2) Legislative and policy issues}

The existence of different legal systems and policies existing between nations that inhibit cross border academic-entrepreneurship. Policy issues act as barriers affecting the ability of academics to move between private and public sectors on temporary basis to develop their discoveries [38].

\section{3) Lack of organisational-owned resources for entrepreneurial ventures}

Academic-entrepreneurs have to deal with an enormous lack of resources, such as time, money and credibility. The required investments required in $R \& D$ are often considerable, while product life cycles are relatively short [39]. Although this problem is inherent to most newly established ventures, it is possibly even stronger in situations where the market is usually small or even non-existent [40].

\section{OPPORTUNITIES FOR ACADEMIC ENTREPRENEURSHIP}

Recent research shows the expansion of the academic entrepreneurship phenomenon.

This section describes entrepreneurial the various existing tangible and intangible academic entrepreneurship opportunities available to the academic entrepreneur, the entrepreneurial academic and the academic-entrepreneur to exploit.

\section{A. Academic Entrepreneur}

\section{1) Universities' intellectual eminence/ faculty quality}

A critical human capital resource for the development of academic entrepreneurship is access to people with expert knowledge and talent. University faculty (academic staff) forms the primary source of this expertise. Research results 
show that more eminent entrepreneurial universities have greater participation rates in academic entrepreneurship than other universities [41].

Given this evidence, then, a university that has built a high-quality faculty, something that takes considerable time, effort, and resources (hence, it is a likely source of competitive advantage) will likely be more successful in their technology transfer efforts than will a university with a faculty of lesser quality [42].

\section{2) Prior entrepreneurial experience}

Entrepreneurship research also highlights that prior entrepreneurial experience increases the probability of identification and exploitation of entrepreneurial opportunities since it helps to develop the mindset and skills necessary to undertake such functions [43].

For example, [44] point to increasing evidence of the phenomenon of recurrent academic entrepreneurs, that is, researchers who undertake multiple entrepreneurial ventures. Prior experience in identifying entrepreneurial opportunities is likely to increase a researcher's perception of the commercial potential of his/her current research activities [7].

\section{B. Entrepreneurial Academic}

\section{1) Access to University venture capital funds}

Access to university venture capital funds influences academics participation in academic entrepreneurship activity. Organizations require incentives and rewards to encourage people to embrace productive activities. Most universities are now giving venture capital funds to support academics to participate in academic entrepreneurship and exploit intellectual property [5].

\section{2) Industry funding of research}

[42] suggest that it is likely that industry R\&D activity helps to stimulate a culture of entrepreneurship within the university. Academics engaged in industry sponsored entrepreneurial activity share their experiences with or involve other academics in their funded research [34]. As a result, the culture may be altered because culture is a reflection of the shared experiences of the members of the organization.

Furthermore, the investment by industry into numerous university research centers likely fosters an entrepreneurial spirit within entrepreneurial academics and the university itself, and builds industry/university linkages that may form the basis for further collaborative endeavors [40].

\section{3) Ties to external academic research network}

Networking and extended social capital have long been associated with the enhancement of entrepreneurial skills. According to [45] associated benefits include; networks enhancing the opportunity recognition capabilities of entrepreneurs, provision of access to critical resources and enable the entrepreneur to capitalise quickly on market opportunities. Indeed, [46] show that exposure to entrepreneurial colleagues increases the propensity of an academic to be entrepreneurial himself. Participation in research collaborations occurs for a range of reasons including: access to complementary expertise; access to additional equipment and resources; and acquisition of prestige, visibility and recognition [47].

\section{Academic-Entrepreneur}

\section{1) Intellectual property transfer policies and strategies}

[41] found that two sets of university licensing policies - policies regarding the distribution of royalties to inventors and whether or not the university is permitted to take an equity stake in licensees - appear to influence entrepreneurial academics. Lower royalty rates may be an incentive to start a venture to exploit a technology rather than license it. In contrast, the ability for academics to take significant equity stakes in spin offs may be a greater incentive for them to create spin offs [48].

\section{2) Licensing/technology transfer policies and strategies}

Introduction of licensing/ transfer policies and strategies are an incentive for academic-entrepreneurs to participate in the creation of new academic entrepreneurship ventures [5]-[6].

\section{3) The quality of academic research}

Entrepreneurial research shows that working at the frontier of research gives academic-entrepreneurs a comparative advantage in identifying new breakthrough opportunities [41]. Moreover, as [28] highlight, the best academic entrepreneurs probably enjoy superior access to high-value knowledge and a stronger natural excludability, leading to a comparatively stronger capacity to identify high-value entrepreneurial opportunities and exploit them.

\section{RECOMMENDATIONS}

Academic entrepreneurship activity should not be solely evaluated via economic returns to the university, academics and stakeholders but should be considered by wider social and economic benefits such as the diffusion of knowledge or the contribution to employment. The areas highlighted below would help the academics, universities and stakeholders involved in academic entrepreneurship perform better.

\section{A. Policies and Strategies}

According to the different universities policies on academic entrepreneurship developed by universities, academic entrepreneurship activity can be encouraged or inhibited. Accordingly, universities must put in place structures to support academics and stake holders in academic entrepreneurship.

\section{B. Stock of Knowledge and Tacit Skills of Academics}

Entrepreneurial universities have the ability to generate a focused strategic direction, both in formulating academic goals and in translating knowledge produced within the university into economic and social utility [20].

Knowledge and tacit skills of academics are the main sources of business opportunities for a university. Therefore it's necessary to develop a data bank about; (a) analysis of captured data for the development of university policies, strategies and initiatives related to academic entrepreneurship, and (b) short, medium and long-term planning: target setting, monitoring of trends and analysis of 
results,

\section{Human Capital}

The potential entrepreneurs that universities possess are a key element determining their academic entrepreneurship performance. The academics all have different individual entrepreneurial orientations impacting their willingness to get involved and performance. Conducting training courses will equip the academics with relevant and up to date skills and competencies to contribute to the transformation of traditional universities into entrepreneurial universities

It must be noted, previous studies on academic entrepreneurship have mainly focused on the United States and selected European countries. According to them, differences in education and public science systems, differences in stages of economic development and differences in patterns of university-industry relations may shape academics' responses to involvement in academic entrepreneurship, as well as the outcomes.

\section{CONCLUSION}

It is necessary that each university develop their own strategic plans that include strategic objectives related to academic entrepreneurship and deliberate on what must be their priorities in order to distribute financial and other kind of resources for their academics. Entrepreneurial universities must be aware that there are different ways to achieve the expected results [28].

\section{ACKNOWLEDGMENT}

A thank you to the Faculty of Business and Design and the Research \& Consultancy Office, Swinburne University of Technology, Sarawak Campus for their belief and continuous support.

\section{REFERENCES}

[1] S. Chen, B. Mulgrew, and P. M. Grant, "A clustering technique for digital communications channel equalization using radial basis function networks," IEEE Trans. on Neural Networks, vol. 4, pp. 570-578, July 1993.

[2] H. Etzkowitz, A. Webster, C. Gebhardt, and B. R. C Terra, "The future of the university and the University of the Future: evolution of ivory tower to entrepreneurial paradigm," Research Policy, vol. 29, no. 2, pp. 313-330, 2000.

[3] R. Florida and W. M. Cohen, "Engine or infrastructure? The university role in economic Development," in Industrializing Knowledge: University-Industry Linkages in Japan and the United States, L. M. Branscomb, F. Kodama, and R. Florida eds., London: MIT Press, 1999 pp. 589-610.

[4] M. Gulbrandsen and S. Slipersæter, "The third mission and the entrepreneurial university model," in Universities and Strategic Knowledge Creation: Specialization and Performance in Europe, A Bonaccorsi and C. Daraio eds., Cheltenham: Edward Elgar, 2007, pp. 112-143.

[5] N. H. Ahmad, H. A. Halim, T. Ramayah, and S. A. Rahman, "Revealing an open secret: Internal challenges in creating an entrepreneurial university from the lens of the academics," International Journal of Conceptions on Management and Social Sciences, vol. 1, no. 1, pp. 2357-2787, 2013.

[6] H. Etzkowitz, "The norms of entrepreneurial science: cognitive effects of the new university-industry linkages," Research Policy, vol. 27, no. 8, pp. 823-833, 1998

[7] H. Etzkowitz, "Research groups as 'quasi-firms': the invention of the entrepreneurial university," Research Policy, vol. 32, no. 1, pp. 109-121, 2003.
[8] J. Bercovitz and M. Feldman, "Academic entrepreneurs Organizational change at the individual level," Organization Science, vol. 19, no. 1, pp. 69-89, 2008

[9] K. Hoye and F. Pries, "Repeat commercializers', the 'habitual entrepreneurs' of university-industry technology transfer," Technovation, vol. 29, pp. 682-689, 2009.

[10] C. Grimpe and H. Fier, "Informal university technology transfer: a comparison between the United States and Germany," Journal of Technology Transfer, in press, 2010.

[11] S. Jain, S. G. George, and M. Maltarich, “Academics or entrepreneurs? investigating role identity modification of university scientists involved in commercialization activity," Research Policy, vol. 38, pp. 922-935, 2009.

[12] D. Sutter, "On the comparative performance of spontaneous orders: academic economics research vs. the market economy," Studies in Emergent Order, vol. 2, pp. 19-37, 2009.

[13] K. K. Jain and M. Yusof, "Leadership challenges in developing an entrepreneurial university," Indian Journal of Training and Development, vol. 31, no. 4, pp. 19-26, 2007.

[14] Malaysian Science and Technology Information Center (MASTIC). (2006), National Survey on Research and Development 2006. Retrieved January 2, 2008, from MASTIC Portal.

[15] B. Clark, Creating Entrepreneurial Universities: Organizational Pathways of Transformation, New York: Pergamon Press, 1998.

[16] B. Sporn, "Building adaptive universities: emerging organisational forms based on experiences of European and US universities," Tertiary Education and Management, vol. 7, no. 2, pp. 121-134, 2001.

[17] H. Etzkowitz, "The evolution of the entrepreneurial university," International Journal of Technology and Globalization, vol. 1, pp. 64-77, 2004

[18] R. Radosevich, "A model for entrepreneurial spin-offs from public technology sources," International Journal of Technology Management, vol. 10, pp. 879-893, 1995.

[19] R. J. W. Tijssen, "Universities and industrially relevant science: toward measurement models and indicators of entrepreneurial orientation," Research Policy, vol. 35, no. 10, pp. 1569-1585, 2006.

[20] M. Yusof and D. W. Sapuan, "Challenges in fostering academic entrepreneurship in the context of science and technology development in Malaysia," Journal of Science and Technology Studies, vol. 6, pp. 49-66, 2008.

[21] M. C. Brennan and P. McGowan, "Academic entrepreneurship: an exploratory case study," International Journal of Entrepreneurial Behavior and Research, vol. 12, no. 3, pp. 44-64, 2006.

[22] E. Coaldrake and L. Stedman, "Academic work in the twenty-first century," Occasional Paper Series, Canberra: Department of Education, Training and Youth Affairs, Higher Education Division, September, 1999.

[23] M. Henrekson and N. Rosenberg, "Designing efficient institutions for science-based entrepreneurship: lessons from the US and Sweden," Journal of Technology Transfer, vol. 26, pp. 207-231, 2001.

[24] B. Perlman, J. Gueths, and D. A Weber, The Academic Intrapreneur: Strategy, Innovation, and Management in Higher Education, New York: Praeger, 1998.

[25] K. Dickson, A. Coles, and H. Smith, "1998 Science in the marketplace: the role of the scientific entrepreneur," in New Technology Based Firms in the 1990s, W. During and Oakey, R. eds., London: Paul Chapman.

[26] P. D. Este and P. Patel, "University-industry linkages in the UK: what are the factors underlying the variety of interactions with industry?" Research Policy, vol. 36, pp. 1295-1313, 2007.

[27] D. J. Evans and M. Klosten, "Comparing academic entrepreneurship in Europe-the case of Sweden and Ireland," Small Business Economics, vol. 14 , no. 4, pp. 299-309, 2000.

[28] B. Gintaras, "Academic entrepreneurship: barriers and fears versus wishes and opportunities," International Journal of Technology Management and Sustainable Development, vol. 11, no. 3, pp. 231-244, 2012.

[29] L. R. D. Silva, "Academic entrepreneurship in a resource constrained environment," PhD dissertation. The University of Manchester, 2012.

[30] C. Monck and N. Segal, "University science parks and small firms," presented at the National Small Business Conference, Durham University, 1983.

[31] OECD, Benchmarking Industry-Science Relationships, Paris, 2002.

[32] OECD, Turning Science into Business, Paris, 2003.

[33] C. A. Bartlett and S. Ghoshal, "Tap your subsidiaries for global reach," Harvard Business Review, vol. 6, no. 46, pp. 87-94, 1986. 
[34] S. J. Kobrin, "Is there a relationship between a geocentric mind-set and multinational strategy?" Journal of International Business Studies, vol. 25, no. 3, pp. 493-511, 1994.

[35] B. J. Cargill, "The entrepreneurial university - is it 'all about the money' or does 'being entrepreneurial' mean something different for a university?" Annual Conference of the British Academy of Management, Belfast, 12-14 September, 2006.

[36] M. Henrekson and N. Rosenberg, "Designing efficient institutions for science-based entrepreneurship: lessons from the US and Sweden," Journal of Technology Transfer, vol. 26, pp. 207-231, 2001.

[37] P. Harveston, "Synoptic versus incremental internationalization: An examination of born global and gradual globalizing firms," $\mathrm{PhD}$ dissertation, The University of Memphis, 2000.

[38] P. McDougall and B. M. Oviatt, "New venture internationalization, strategic change, and performance: a follow-up study," Journal of Business Venturing, vol. 11, no. 1, pp. 23-40, 1996.

[39] I. A. M. Wakkee, A. J. Groen, and W. E. During, "Global start-ups: definition and identification," a paper presented at the ninth HTSF conference, May 2001, Manchester UK., 2001.

[40] D. D. Gregorio and S. Shane, "Why do some universities generate more start-ups than others?" Research Policy, vol. 32, no. 2, pp. 209-227, 2003

[41] J. B. Powers and P. P. McDougall, "University start-up formation and technology licensing with firms that go public: a resource-based view of academic entrepreneurship," vol. 20, pp. 291-311, 2005.

[42] S. Shane and S. Venkataraman, "The promise of entrepreneurship as a field of research," The Academy of Management Review, vol. 25, no. 1, pp. 217-26, 2000.

[43] M. Wright, S. Birley and S. Mosey, "Entrepreneurship and university technology transfer," Journal of Technology Transfer, vol. 29, pp. 235-246, 2004.

[44] K. Hoye and F. Pries, "Repeat commercializers', the 'habitual entrepreneurs' of university-industry technology transfer," Technovation, vol. 9, pp. 682-689, 2009.

[45] G. Hills, G. T. Lumpkin, and R. P. Singh, "Opportunity recognition: perceptions and behaviors of entrepreneurs," 1997.

[46] G. Bammer, "Enhancing research collaborations: three key management challenges," Research Policy, vol. 37, no. 5, pp. 875-887, 2008.

[47] G. D. Markman, P. H. Phan, D. B. Balkin, and P. T. Gianiodis, "Entrepreneurship and university-based technology transfer," Journal of Business Venturing, vol. 20, no. 2, pp. 241-263, 2005.
[48] C. Franzoni and F. Lissoni, "Academic entrepreneurship: critical issues and lessons for Europe," in Academic Entrepreneurship and Regional Development, A. Varga ed., Edward Elgar, forthcoming, 2007

[49] European Commission 2000, "Innovation in a knowledge-driven economy," Communication from the Commission to the Council and the European Parliament, September 20, 2000.

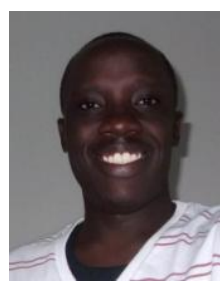

Kizito Emmanuel Nyeko is currently a full-time postgraduate research candidate at the Faculty of Business and Design, Swinburne University of Technology, (Sarawak Campus) Malaysia. His research focus is on the area of entrepreneurship in academia and industry.

While pursuing his studies, Kizito Emmanuel is also gaining valuable experiences as a research and teaching assistant in the field of business and management studies. Prior to joining Swinburne, he was employed as a finance and audit officer in the public service of the republic of Uganda and as an accounts assistant in a private insurance firm. These work engagements exposed him to various practices in human resource management, accounting and finance, strategic management in industry and public service.

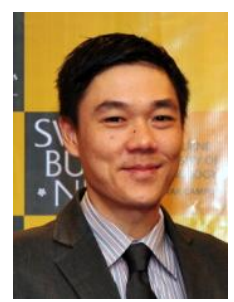

Ngui Kwang Sing received a $\mathrm{PhD}$ in human resource development from Universiti Malaysia Sarawak, a MSc (Distinction) in human resource management from University of Leicester and a BA in Business Administration from Royal Melbourne Institute of Technology University.

$\mathrm{He}$ is a senior lecturer at the Faculty of Business \& Design, Swinburne University of Technology (Sarawak Campus), where he teaches courses in leadership, human resource management and entrepreneurship. He has published works on organisational learning, high-performance human-resource practices and industry competitiveness, and has attracted research fundings for studies on diversification patterns of public-listed firms in Malaysia, leadership behaviours and industry competitiveness. 